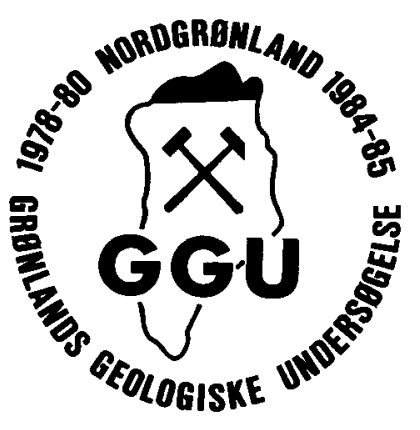

\title{
Additions to the lithostratigraphy of the Peary Land Group (Silurian) in western and central North Greenland
}

\author{
P.-H. Larsen and J. C. Escher
}

\begin{abstract}
New information is given on the areal extent, thickness, age and general field occurrence of the Silurian Peary Land Group. One new formation (Nyeboe Land Formation), three new members (Kap Brevoort, Hand Bugt and Castle $\emptyset$ ) are added to the established stratigraphy. The Lauge Koch Land Formation, Repulse Havn Member and Hendrik $\emptyset$ Member are redefined.
\end{abstract}

P.-H. L. \& J. C. E., Grønlands Geologiske Undersøgelse, $\emptyset$ ster Voldgade 10, DK-1350 Copenhagen K, Denmark.

The Peary Land Group (fig. 1) was erected by Hurst (1980, p. 73). A detailed lithostratigraphic scheme and environmental interpretation, as well as a comprehensive review of historical aspects, are given by Hurst \& Surlyk (1982). This paper adds one new formation and three new members to the established stratigraphic scheme (fig. 2), on the basis of new field work by the authors in 1984-85 in western and central North Greenland. The distribution of the formations and members of the group is shown in fig. 3 and the units are briefly described here with emphasis on new information concerning their areal extent, thickness and age. The redefinition integrates informal units by Dawes \& Peel (1984) and Larsen \& Escher (1985) employed with the lithostratigraphic scheme introduced by Hurst \& Surlyk (1982).

\section{Merqujôq Formation}

The formation was erected by Hurst \& Surlyk (1982) and consists of sandstone turbidites, interbedded mudstone and carbonate conglomerates. The Merqujôq Formation occurs between Peary Land in the east (Hurst \& Surlyk, 1982) and northern Nyeboe Land in the west (Larsen \& Escher, 1985). It includes 'unit 3A' of Dawes \& Peel (1984) on Hendrik $\emptyset$. The formation does not occur in Hall Land.

In Peary Land carbonate boulder conglomerates within the turbidite sequence are distinguished as the Freja Fjord and Citronens Fjord Members (Hurst \& Surlyk, 1982). A major carbonate boulder conglomerate unit found in the basal part of the formation in western North Greenland is here described as a new member; the Kap Brevoort Member. A carbo- 


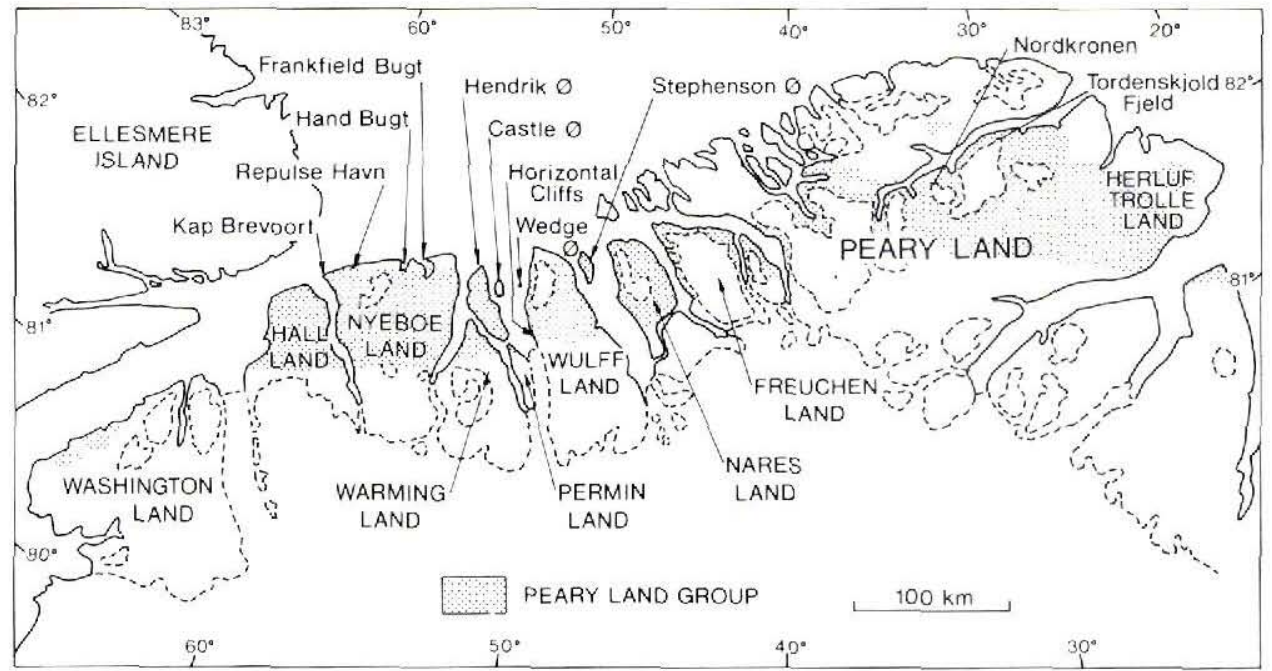

Fig. 1. Locality map of North Greenland showing geographical names mentioned in the text. The distribution of the Peary Land Group is indicated.

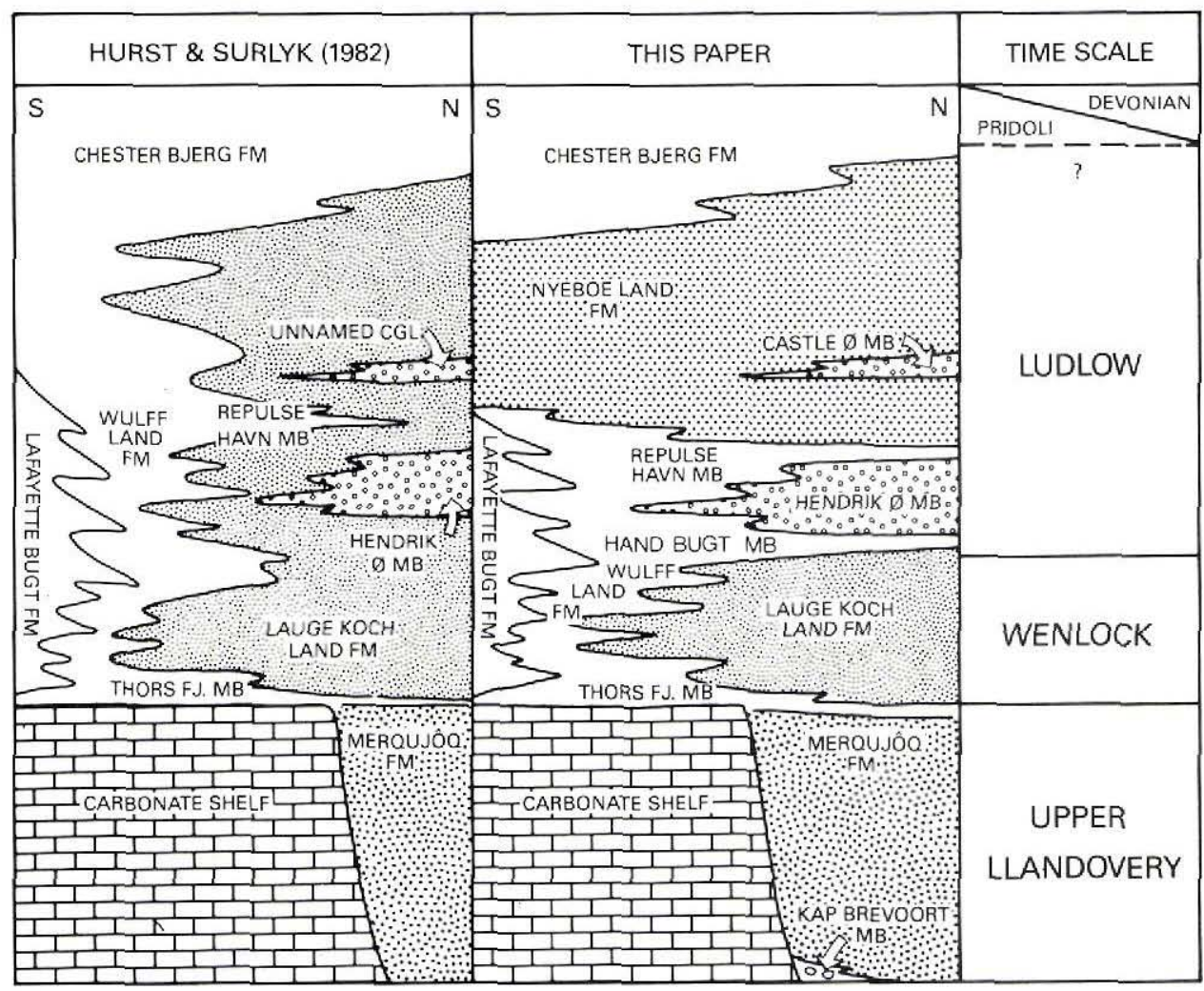

Fig. 2. Correlation between the lithostratigraphic scheme of the Peary Land Group in western and central North Greenland adapted from Hurst \& Surlyk (1982, fig. 2) and that proposed in this paper. The schemes represent south to north sections in the Hendrik $\emptyset$ - Wulff Land area. 


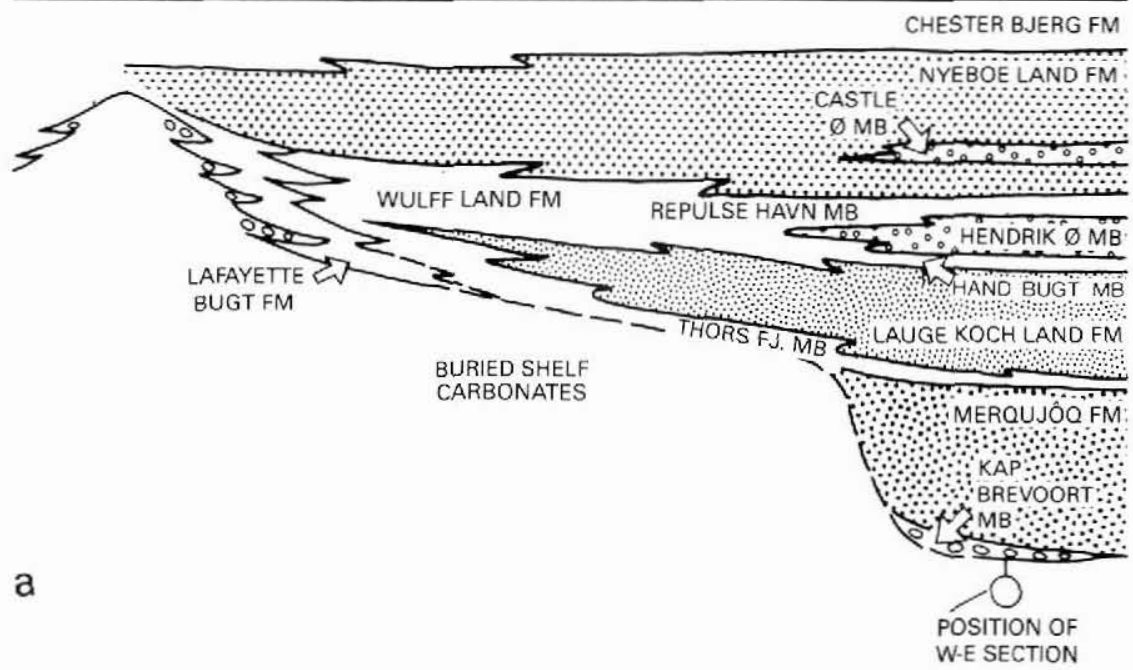

W FRANKFIELD BUGT

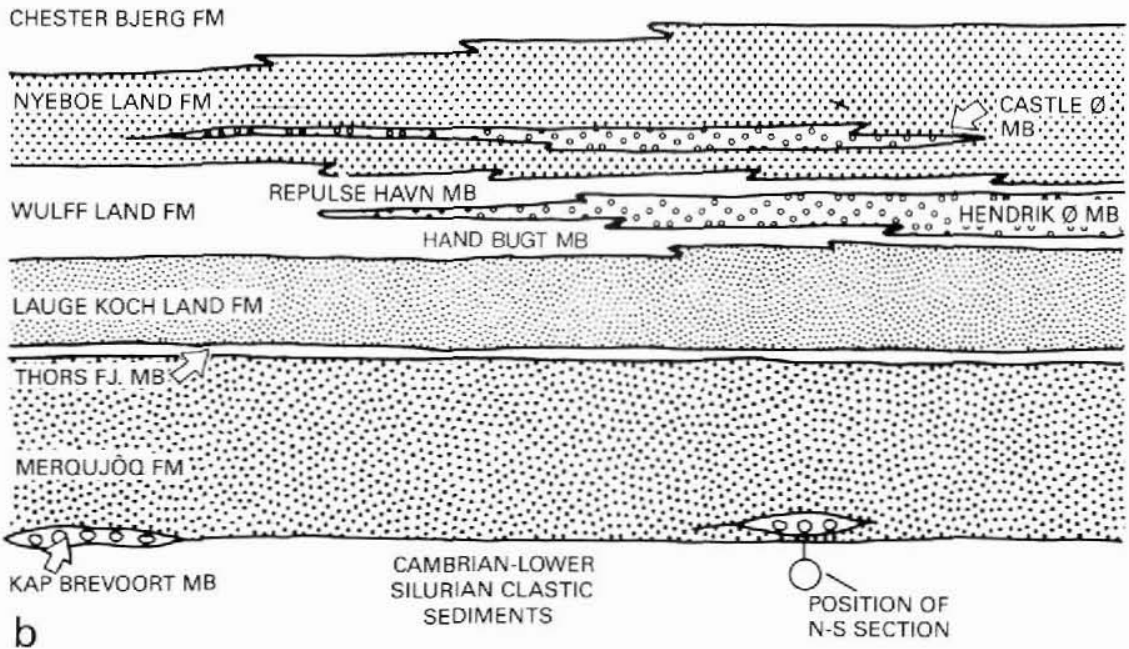

Fig. 3. Schematic cross-sections showing the distribution of the Silurian formations and members of the Peary Land Group in western and central North Greenland; (a) south to north section in the Hendrik $\emptyset$ - Wulff Land area; (b) west to east section of the deepest part of the basin from Hall Land to the Nares Land - Freuchen Land area. 


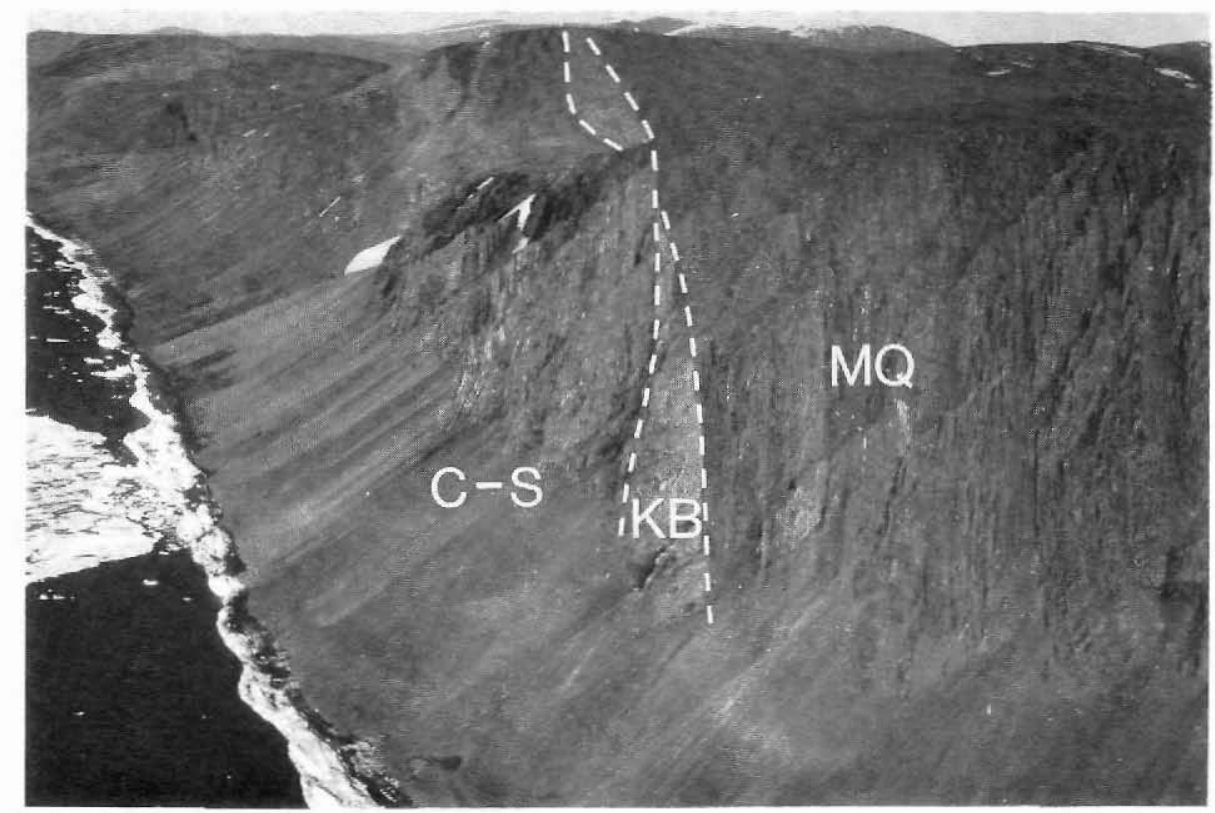

Fig. 4. Northern Nyeboe Land just east of Kap Brevoort. The steeply dipping carbonate conglomerates of the Kap Brevoort Member (KB) overlie Cambrian - Lower Silurian clastic sediments (C-S) and are overlain by sandstone turbidites of the Merqujôq Formation (MO). Stratigraphic top to the right. Hight of cliff about $600 \mathrm{~m}$.

nate conglomerate unit occurring in the top of the formation in Navarana Fjord is described as the Navarana Fjord Member by Surlyk \& Ineson (1987).

\section{Kap Brevoort Member}

new member

Name. After Kap Brevoort, the extreme north-west point of Nyeboe Land (fig. 1).

Type locality. A gully just east of Kap Brevoort (fig. 4). Reference localities occur in northern Nyeboe Land. The easternmost reference locality is in northern Wulff Land.

Thickness. Between 5 and $100 \mathrm{~m}$.

Lithology. Carbonate conglomerates composed of angular to rounded blocks characterise the member. The carbonates of the clasts and the matrix are grey and totally recrystallised. Post-depositional deformation and shearing makes it difficult to delineate individual clasts. At the type locality in northern Nyeboe Land the member probably only consists of a single bed reaching a thickness of approximately $60 \mathrm{~m}$ (fig. 4). In northern Wulff Land the member 
may consist of two amalgamated beds interfingering with a shale unit and the total thickness of the carbonate conglomerates reaches $100 \mathrm{~m}$.

Depositional environment. The conglomerates were deposited from debris flows derived from the contemporaneous carbonate platform situated approximately $10 \mathrm{~km}$ to the south (see discussion in Escher \& Larsen, 1987). Today this carbonate platform escarpment is only exposed in Navarana Fjord.

Fauna and age. Possibly deposited within the turriculatus or the spiralis Zones of the Late Llandovery based on faunal evidence from the basal parts of the Merqujôq Formation (Higgins \& Soper, 1985; Larsen \& Escher, 1985; Escher \& Larsen, 1987). Conodont assemblages collected from the carbonate clasts within the conglomerates show clast ages from Middle Ordovician to Lower Silurian (R. J. Aldridge, personal communication, 1986).

Boundaries. The member forms the base or interfingers with the lowermost beds of the Merqujôq Formation, and overlies Ordovician and possibly Lower Silurian mudstones and cherts which form the top of the Cambrian - Lower Silurian starved basin sequence described by Higgins \& Soper (1985) (fig. 4).

Distribution. The Kap Brevoort Member is well exposed along the north coast of Nyeboe Land between Kap Brevoort and Repulse Havn (fig. 4). It probably consists of a single bed which shows rapid variations in thickness along strike (east-west) between 5 and $60 \mathrm{~m}$. In northern Wulff Land a $100 \mathrm{~m}$ thick unit of resedimented carbonate conglomerates occurs in an exposure of vertical dipping strata. Here the member probably consists of two amalgamated beds which can be traced approximately $2 \mathrm{~km}$ along strike from east to west.

\section{Lafayette Bugt Formation}

The formation was erected by Hurst (1980) in Washington Land and western Hall Land. Hurst \& Surlyk (1982) described the formation from localities in Nyeboe Land, Warming Land and Wulff Land, where it comprises thick, black mudstone units interbedded with lime mudstones, calcarenitic turbidites and carbonate conglomerates. The Lafayette Bugt Formation has not been observed east of Wulff Land.

Redeposited limestone conglomerates are a diagnostic feature of the formation and these tend to occur sporadically around the carbonate build-ups along the southern carbonate platform margin. The limestone conglomerates have even been observed interbedded with the sandstone turbidites of the Nyeboe Land Formation (see below). However, where the limestone conglomerates are absent, the mudstone units of the Lafayette Bugt Formation are indistinguishable from the mudstone units of the Wulff Land Formation. Larsen \& Escher (1985) mentioned the difficulties in separating the Lafayette Bugt Formation from the Wulff Land Formation because of their similar lithologies (see also Dawes \& Peel, 1984, p. 36). Field work in 1984-1985 showed that the Lafayette Bugt Formation is not a mappable unit in much of western North Greenland, east of Washington Land, and the mudstone units are here mapped as Wulff Land Formation.

The Lafayette Bugt Formation represents an important slope facies adjacent to the carbonate build-ups which occur to the south in the deep-water basin. 


\section{Wulff Land Formation}

The formation was erected by Hurst \& Surlyk (1982) for a sequence of black mudstones and fine-grained black or green siltstones. The formation is subdivided into three members: the Thors Fjord Member, the redefined Repulse Havn Member and the new Hand Bugt Member.

\section{Thors Fjord Member}

The member was erected by Hurst \& Surlyk (1982) and mapped in western North Greenland by Larsen \& Escher (1985). On Hendrik Ø it corresponds to 'unit 3B' of Dawes \& Peel (1984). In 1985 field work showed that it also occurs in northern Hall Land on top of the carbonate shelf sequence (Escher \& Larsen, 1987) where it corresponds to 'unit 1F' of Dawes \& Peel (1984).

Graptolite assemblages collected within the Thors Fjord Member in Hall Land include Monograptus spiralis, M. priodon, M. tullbergi (?)spiraloides, Monoclimacis vomerina and Stomatograptus grandis indicating the spiralis Zone of Late Llandovery (M. Bjerreskov, personal communication, 1986).

\section{Repulse Havn Member}

redefined

The member was erected by Hurst \& Surlyk (1982) for a sequence of thin-bedded mudstone and siltstone turbidites set against a background of silty mudstone. A characteristic feature of the member is the heavy bioturbation of the sediments.

The type section is in northern Nyeboe Land $5 \mathrm{~km}$ due south of Repulse Havn (Hurst \& Surlyk, 1982, plate 2, section 22). However, recent field work has shown that the approximately $200 \mathrm{~m}$ of mudstones and siltstones defined by Hurst \& Surlyk (1982) as the stratotype of the Repulse Havn Member is only a part of a sequence of approximately $650 \mathrm{~m}$ of mudstones interbedded with occasional $20-30 \mathrm{~m}$ sandstone packages occurring in northern Nyeboe Land and Hall Land (fig. 3b).

East of Frankfield Bugt in northern Nyeboe Land conglomerates associated with sandstone turbidites of the Hendrik $\varnothing$ Member (see below) of the Nordkronen Formation interfinger with this thick mudstone dominated sequence (fig. 3b) dividing it into two units which respectively overlie and underlie the Hendrik $\emptyset$ Member. It is the upper sequence which was defined as the Repulse Havn Member by Hurst \& Surlyk (1982).

In order to obtain a clear and practical nomenclature of the lithostratigraphic units F. Surlyk (personal communication, 1986) suggested that the Repulse Havn Member be redefined to comprise only the mudstone-dominated unit overlying the conglomerates of the Hendrik $\emptyset$ Member east of Frankfield Bugt (Hurst \& Surlyk, 1982, figs 81, 87, 88). The redefinition is proposed here. On Hendrik $\varnothing$ Dawes \& Peel (1984) termed this unit '3E' and '3F'. The mudstone unit underlying the conglomerates of the Hendrik $\varnothing$ Member is proposed as a new member of the Wulff Land Formation: the Hand Bugt Member (fig. 3) (see below).

West of Frankfield Bugt no clear lithological subdivisions occur within the approximately $650 \mathrm{~m}$ thick mudstone-dominated sequence, containing the stratotype of the Repulse Havn 


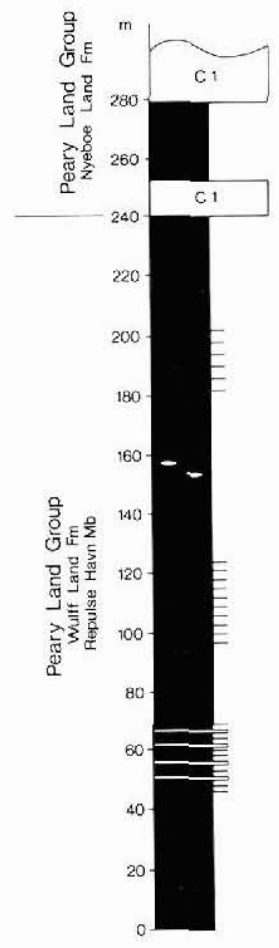

Fig. 5. Section 13 measured in 1985, showing a reference section of the Repulse Havn Member of the Wulff Land Formation on the north-east coast of Castle $\varnothing$. Facies scheme is adopted from Hurst \& Surlyk (1982, fig. 6) as slightly modified by Larsen \& Escher (1985).

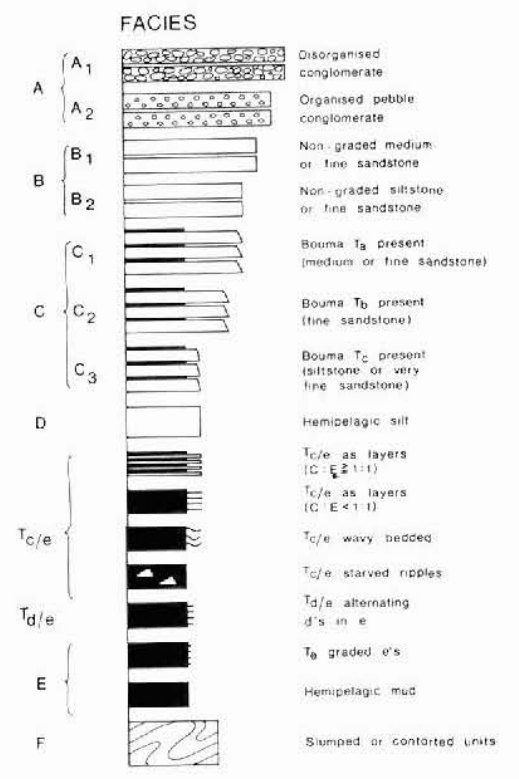

Member as described above. We propose that this $650 \mathrm{~m}$ thick sequence as a whole be referred to as undivided Wulff Land Formation (fig. 3b). The occasional $20-30 \mathrm{~m}$ sandstone packages and individual fine sandstone turbidites within this succession are interdigitations of the Lauge Koch Land Formation and Nyeboe Land Formation in the lower and upper parts of the sequence, respectively.

The distribution of the Repulse Havn Member thus extends from Frankfield Bugt in northern Nyeboe Land eastwards to Freuchen Land. The member overlies the Hendrik $\emptyset$ Member of the Nordkronen Formation and underlies and interfingers with the Nyeboe Land Formation (see below).

The thickness of the Repulse Havn Member is approximately $250 \mathrm{~m}$ on Hendrik $\varnothing$ (Dawes \& Peel, 1984, units 3E and 3F) and has been measured to $240 \mathrm{~m}$ in Castle $\varnothing$ (fig. 6).

From the reference section of the Repulse Havn Member on Hendrik $\varnothing$. Hurst \& Surlyk (1982, p. 70) reported Monoclimacis sp., Pristiograptus dubius ?ludlowensis, P. dubius and Bohemograptus bohemicus. In addition Berry et al. (1974), Dawes (1976) and Dawes \& Peel (1984) reported Pristiograptus sp., B. bohemicus?tenuis and Saetograptus fritschi. The graptolites indicate an Early to Middle Ludlow age. Neolobograptus aff. N. auriculatus, Lobograptus aff. L. progenitor, S. ?leintwardinensis, S. fritschi linearis, P. ex. gr. P. dubius, B. bohemicus and Monograptus sp. have been collected from a reference section (fig. 5) on Castle $\varnothing$, and indicate a Middle Ludlow age. On Stephenson $\varnothing$ B. bohemicus bohemicus occurs in the Repulse Havn Member, also indicating an Early to Middle Ludlow age. 


\section{Hand Bugt Member}

new member

History. The member corresponds to the eastern part of the mudstone and siltstone dominated sequence referred to as the 'Hand Bugt beds' by Larsen \& Escher (1985, fig. 1) and used as a distinctive marker unit.

Name. From Hand Bugt in northern Nyeboe Land (fig. 1).

Type section. The type section is located in a north-south trending valley at the northern end of Hendrik $\emptyset$, just below the type section of the Hendrik $\emptyset$ Member of the Nordkronen Formation (fig. 6). Reference sections occur on northern Castle $\emptyset$, southern Stephenson $\emptyset$ and along the east coast of Nares Land.

Thickness. In the type section the thickness exceeds $80 \mathrm{~m}$. On Stephenson $\emptyset$ the cumulative thickness of two wedges of the member reaches $200 \mathrm{~m}$.

Lithology. The member is characterised by thin-bedded green to brownish red, silty mudstone turbidites set against a background of silty mudstone. As a result of uniform fine silt, layering is often only indicated by the colour banding from green to brownish red. The silty mudstone is often interbedded with medium to thick-bedded, calcareous, silty sandstone turbidites. The sandy turbidites have a dark red, rusty weathering colour which is conspicuous throughout the unit. Sandstone layers dominated by crinoid and brachiopod debris are commonly associated with the sandy turbidites (fig. 6). Bioturbation is characteristic of the member and trace fossils are abundant on the soles of the silty, very fine sandstone units.

Depositional environment. The member probably represents basin plain, distal outer fan or fan fringe depositional environments. The content of crinoid and brachiopod debris in the sandy turbidites interbedded with the silty mudstones indicates clastic input into the basin from the contemporaneous carbonate platform to the south. The characteristic bioturbation of the silty mudstones indicates a period of oxygenation of the bottom sediments over a wide area of the basin, in line with analogous conditions prevailing during the deposition of the Repulse Havn Member described by Hurst \& Surlyk (1982).

Boundaries. The member interfingers with the Lauge Koch Land Formation. Often two or more reddish brown coloured wedges are observed interbedded with units of buff-yellow sandstone turbidites of the Lauge Koch Land Formation. The lower boundary of the Hand Bugt Member is placed at the base of the first thick unit of greenish to brownish red siltstone or mudstone turbidites. The upper boundary is placed at the top of the last thin-bedded siltstone or mudstone turbidite unit, which is succeeded by chert pebble conglomerates of the Hendrik $\emptyset$ Member of the Nordkronen Formation (fig. 6).

Distribution. The Hand Bugt Member occurs as a distinct band (due to almost vertical dips) across northern Nyeboe Land east of Frankfield Bugt, northern Hendrik $\emptyset$ and Castle $\emptyset$. The member occurs as two distinct layers interfingering with the Lauge Koch Land Forma- 


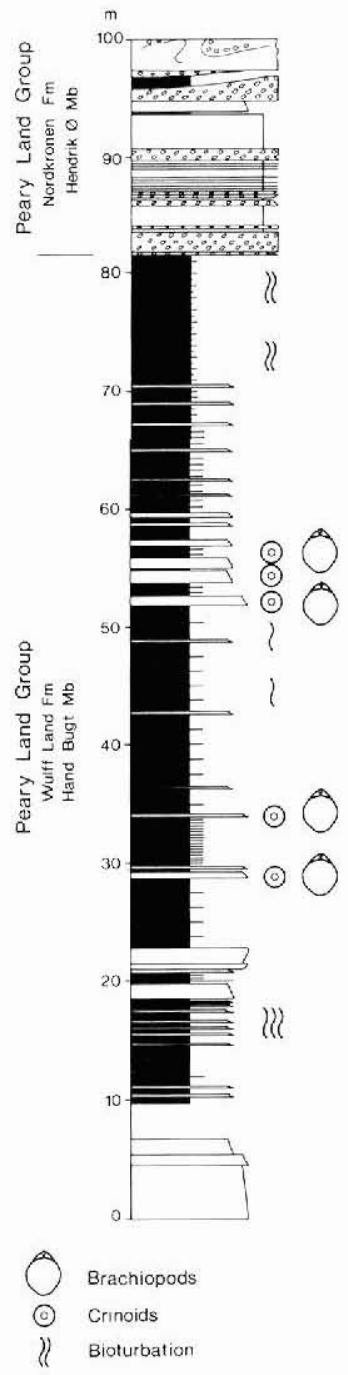

Fig. 6. Section 16 measured in 1984, showing the type section of the Hand Bugt Member of the Wulff Land Formation on Hendrik $\emptyset$.

tion across northern Wulff Land, southern Stephenson $\varnothing$ and Nares Land to the west coast of Freuchen Land.

Geological age. Graptolite assemblages collected in the type section on Hendrik $\varnothing$ include Pristiograptus dubius aff. ?ludlowensis. From the member on Castle $\varnothing$ Bohemograptus? n.sp. was recovered and on Stephenson $\varnothing$ B. bohemicus, $P$. ex. gr. P. dubius and Monograptus sp. Along the east coast of Nares Land the following assemblages were collected: Monograptus sp., P. ex. gr. P. dubius and $M$. sp. aff. M. scanicus. These graptolites indicate an Early to Middle Ludlow age, in agreement with the Early to Middle Ludlow fauna reported from the overlying Repulse Havn Member, described above, and with the Middle to Late Wenlock fauna reported from the underlying Lauge Koch Land Formation (Hurst \& Surlyk, 1982; Larsen \& Escher, 1985). 


\section{Lauge Koch Land Formation}

redefined

The formation was erected by Hurst \& Surlyk (1982). As originally defined it was divided into two units by a distinctive sequence of strata including the Hendrik $\emptyset$ Member of the Nordkronen Formation and the Repulse Havn and Hand Bugt Members of the Wulff Land Formation. These two units of the original Lauge Koch Land Formation were referred to as lower and upper mapping units, respectively, by Larsen \& Escher (1985). Of these, the upper mapping unit is only known west of Navarana Fjord.

We propose here that the Lauge Koch Land Formation be redefined west of Navarana Fjord so as to comprise only the lower mapping unit of Larsen \& Escher (1985); this corresponds to units ' $1 G$ ' and ' $3 C$ ' of Dawes \& Peel (1984) in Hall Land and on Hendrik $\varnothing$. The upper mapping unit of Larsen \& Escher (1985) is described below as the Nyeboe Land Formation of the Peary Land Group.

\section{Nyeboe Land Formation}

new formation

History. The formation corresponds, in part, to the Lauge Koch Land Formation, as originally defined by Hurst \& Surlyk (1982). It thus corresponds to the upper mapping unit of the Lauge Koch Land Formation as used by Larsen \& Escher (1985). It includes unit '3G' of Dawes \& Peel (1984) on Hendrik $\emptyset$.

Name. After Nyeboe Land (fig. 1).

Type section. The type section (figs $7,8,9$ ) is at Horizontal Cliffs on the west coast of Wulff Land (fig. 10). Reference sections occur along the steep cliffs along the east coasts of Nyeboe Land and Hendrik $\emptyset$. Reference sections from Hand Bugt and north-east Nyeboe Land are presented in Larsen \& Escher (1985, figs 6, 7).

Thickness. Approximately $1000 \mathrm{~m}$ measured in Hand Bugt, northern Nyeboe Land.

Lithology. The formation is characterised by buff-yellow to brown weathering, medium to thick-bedded sandy turbidites (figs 7,9 ). Thinner-bedded, finer-grained siltstone and mudstone units also occur, but the sand/mud ratio is generally $>1$ (figs 7,8 ).

Fauna and age. There is no graptolite evidence from the formation to indicate age. However, in northern outcrops the underlying Repulse Havn Member of the Wulff Land Formation has yielded Early to Middle Ludlow graptolite assemblages (see above). Near the southern margin of the deep-water basin, adjacent to the carbonate platform, graptolite assemblages collected from just below the base of the formation also indicate an Early to Middle Ludlow age (Hurst \& Surlyk, 1982; Dawes \& Peel, 1984; Larsen \& Escher, 1985; Larsen et al., 1987). The Nyeboe Land Formation seems therefore to be no older than Early Ludlow in western North Greenland.

The Nyeboe Land Formation is stratigraphically overlain by the Chester Bjerg Formation, which in Hall Land has yielded graptolite assemblages of Pridoli age (Berry et al., 1974; 
Fig. 7. Section 14 measured in 1985 , showing the type section of the Nyeboe Land Formation at the west coast of Wulff Land (fig. 10). Lines a-b and c-d indicate parts of the section which have been expanded and shown in figs 8 and 9 .

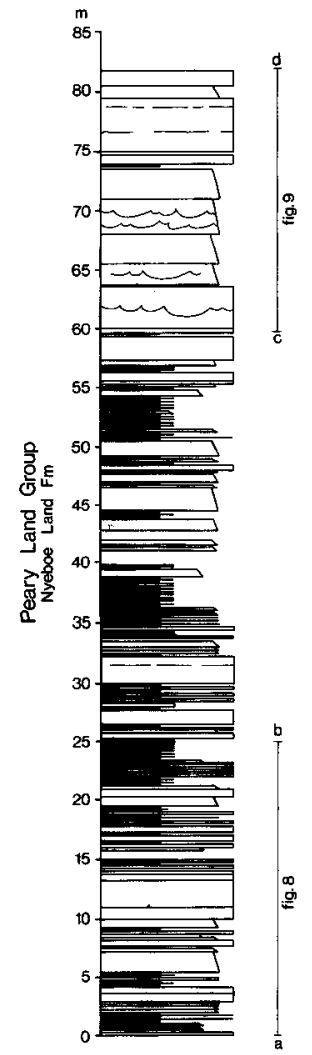

Hurst \& Surlyk, 1982; Dawes \& Peel, 1984). In north-east Nyeboe Land finds of Pristiograptus dubius in the Chester Bjerg Formation indicate that the age of the base of this formation might be older than Pridoli. The age of the Nyeboe Land Formation seems therefore to be Ludlow, possibly hate Ludlow.

Several localities within the formation have yielded plant megafossils (Larsen, et al., 1987).

Boundaries. The formation overlies and interdigitates with the Wulff Land Formation between Hall Land and Freuchen Land. East of Frankfield Bugt, and as far eastward as Freuchen Land, the formation overlies and interfingers with the Repulse Havn Member of the Wulff Land Formation (fig. 2). The Nyeboe Land Formation is overlain by and interfingers with the Chester Bjerg Formation (figs 2, 3; Larsen \& Escher, 1985, p. 56 and fig. 2).

Distribution. The Nyeboe Land Formation occurs between Hall Land and the west coast of Freuchen Land (Larsen \& Escher, 1985, fig. 1). The formation is not preserved east of Freuchen Land, where it has probably been removed by modern erosion. 


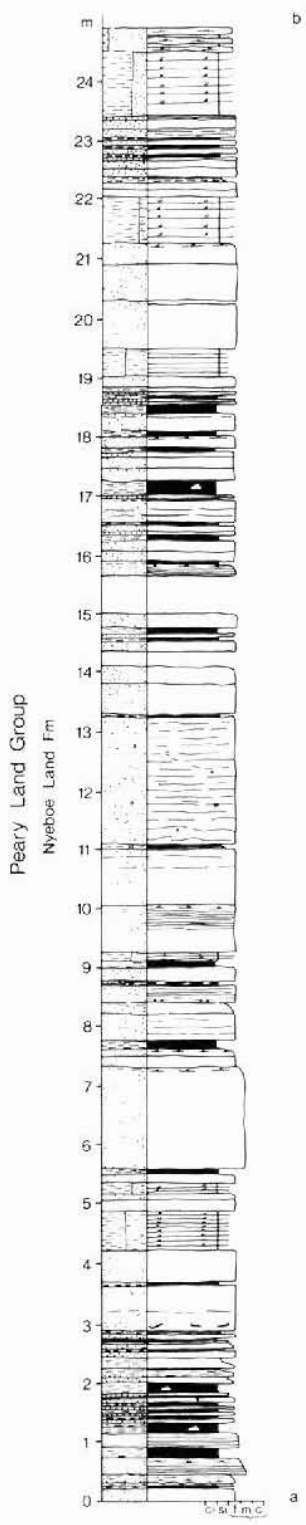

Fig. 8. Details of sediment $\log$ of the Nyeboe Land Formation from section 14 (fig. 7, a-b) in the type section (fig. 10).

Fig. 9. Details of sediment log of the Nyeboe Land Formation from section 14 (fig. 7, c-d) in the type section (fig. 10).






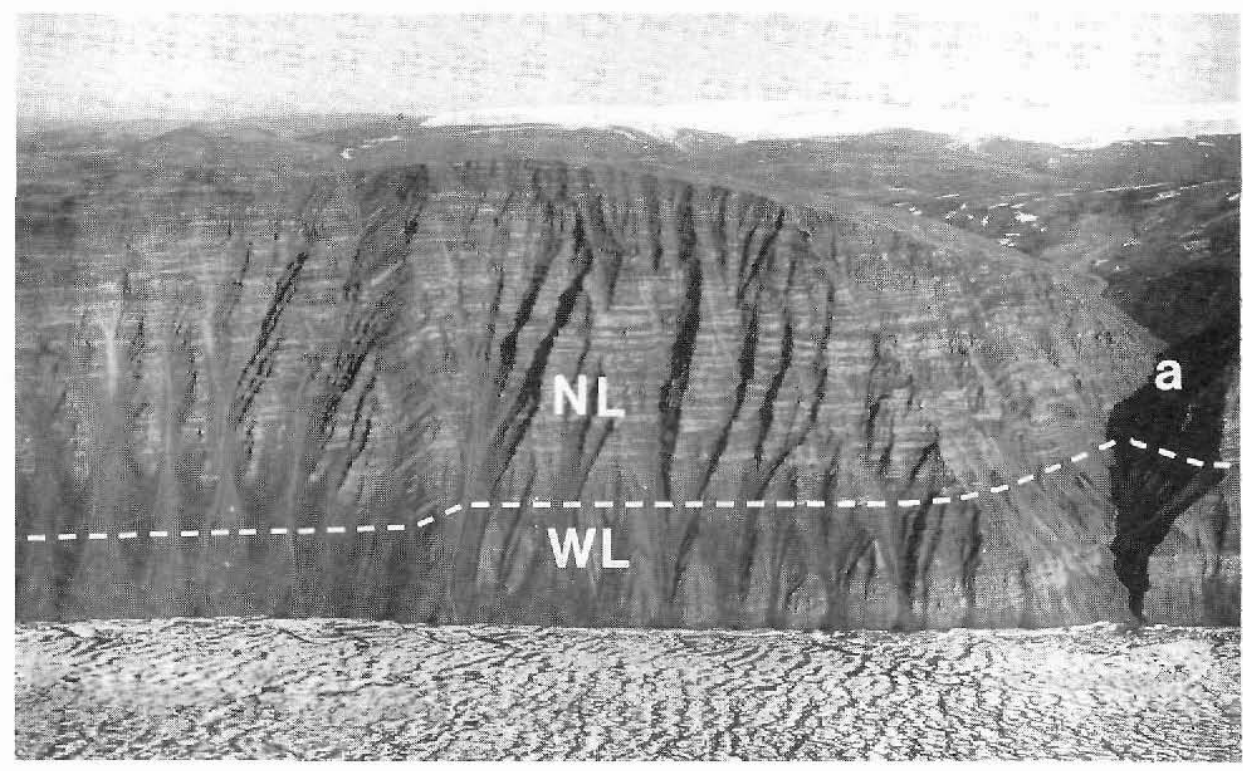

Fig. 10. Horizontal Cliffs at the west coast of Wulff Land showing the gully (a) which is the location of the type section (fig. 7) of the Nyeboe Land Formation. Cliff height approximately $600 \mathrm{~m}$. Nyeboe Land Formation (NL) overlies black mudstones of the Wulff Land Formation (WL).

\section{Nordkronen Formation}

The formation was erected by Hurst \& Surlyk (1982) and comprises a sequence of chert pebble conglomerates, pebbly sandstones and sandstones. The main distribution is in Herluf Trolle Land and the hill tops of Nordkronen and Tordenskjold Fjeld in Peary Land (Hurst \& Surlyk, 1982). Two members of the formation, the Hendrik $\varnothing$ and Castle $\varnothing$ Members, have been traced almost continuously between Freuchen Land and northern Nyeboe Land (Larsen \& Escher, 1985).

\section{Hendrik Ø Member}

redefined

History. Dawes $(1966,1976)$ introduced the name 'Hendrik conglomerate' for a conglomerate-bearing sequence about $250 \mathrm{~m}$ thick on Hendrik $\varnothing$. Hurst \& Surlyk (1982) logged only the upper $15 \mathrm{~m}$ of this sequence, defining these beds as the Hendrik $\emptyset$ Member. Larsen \& Escher (1985) mapped the conglomerate-bearing sequence as a narrow strip from Frankfield Bugt in Nyeboe Land, across Hendrik $\varnothing$, Castle $\varnothing$, Wulff Land and Stephenson $\varnothing$, and referred to it informally as 'Hendrik $\varnothing$ unit A'. On Hendrik $\varnothing$ it corresponds to Dawes' original 'Hendrik conglomerate' (see also Dawes \& Peel, 1984, fig. 3, unit 3D). This sequence is redefined here as the Hendrik $\varnothing$ Member.

Name. After the island Hendrik $\varnothing$ (fig. 1). 
Type and reference sections. The type section is located in the north-south trending valley at the north end of Hendrik $\emptyset$ (fig. 6). Larsen \& Escher (1985, fig. 3) published a log through the base of the type section using the informal name 'Hendrik $\emptyset$ unit $A$ ', while Hurst \& Surlyk (1982, fig. 120) presented a log of the top of the type section. Reference sections occur on Castle $\emptyset$ and Stephenson $\emptyset$.

Thickness. The thickness of the member increases progressively from west to east: near Frankfield Bugt only $32 \mathrm{~m}$ are exposed, on Hendrik $\emptyset 281 \mathrm{~m}$ were measured and on Stephenson $\varnothing$ some $300-400 \mathrm{~m}$ occur.

Lithology. The Hendrik $\emptyset$ Member is characterised by resedimented chert pebble conglomerates interbedded with fine sandstone turbidites and a few mudstone sequences (Larsen \& Escher, 1985, fig. 3). The conglomerate/sandstone ratio decreases stratigraphically upwards and gives way to almost pure fine sandstone and siltstone turbidites at the top. The fine sandstone turbidites are closely associated with the chert pebble conglomerates which were deposited from high-density turbidity currents (Hurst \& Surlyk, 1982; Surlyk \& Hurst, 1984).

Fauna and age. No fossils have been collected from the Hendrik $\emptyset$ Member, but faunas from underlying and overlying units, noted elsewhere, indicate an Early Ludlow age.

Boundaries. The member overlies the Hand Bugt Member and underlies the Repulse Havn Member of the Wulff Land Formation (fig. 3).

Distribution. The member can be traced from Frankfield Bugt in Nyeboe Land eastwards to the west coast of Freuchen Land.

\section{Castle $\varnothing$ Member}

new member

History. The member comprises 'the upper chert pebble conglomerate' observed by $\mathbf{P}$. R. Dawes in 1966 on Hendrik $\varnothing$ (personal communication, 1984), also mentioned by Hurst \& Surlyk (1982, p. 103 and fig. 81) as the 'Hendrik $\varnothing$ Member (B)'. The uncertain relationship between the two conglomerates occurring on Hendrik $\emptyset$ was unravelled by Larsen \& Escher (1985) who showed that the conglomerates were mappable as two discrete units. They referred to the upper unit as 'Hendrik $\varnothing$ unit B' and this unit is distinguished here as a new member, the Castle $\varnothing$ Member of the Nordkronen Formation.

Name. After the island Castle $\varnothing$ (fig. 1).

Type and reference sections. The type section (fig. 11) is located in the north-south trending valley at the northern end of Castle $\varnothing$. Reference sections are located in Repulse Havn, Hand Bugt and Frankfield Bugt in northern Nyeboe Land, and on Hendrik $\emptyset$ (fig. 12).

Thickness. Approximately $15-30 \mathrm{~m}$. 


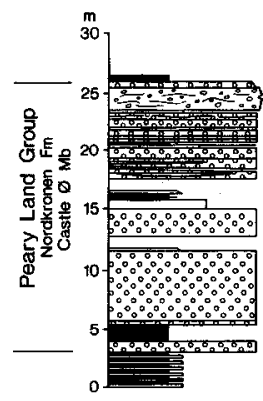

Fig. 11. Section 11 measured in 1985 , showing the type section of the Castle $\emptyset$ Member (Nordkronen Formation) in the north-south trending valley on northern Castle $\emptyset$.

Fig. 12. Detailed log of a reference section of the Castle $\varnothing$ Member (Nordkronen Formation) in Hendrik $\emptyset$. Note the channelling.

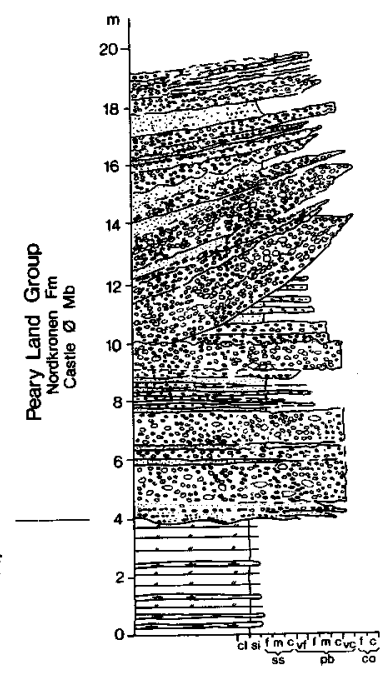

Lithology. The member is characterised by chert pebble conglomerates interbedded with fine sandstone turbidites (fig. 11). The conglomerates occur in channels (fig. 12), and wedgeshaped beds showing lateral accretion indicate the meandering nature of the channels.

Fauna and age. No fossils have been recovered from the Castle $\emptyset$ Member, but stratigraphic relationships indicate that it cannot be older than Early Ludlow.

Boundaries. The member interfingers with the Nyeboe Land Formation, and normally occurs within this formation approximately $100 \mathrm{~m}$ above its base.

Distribution. The member can be traced from Castle $\varnothing$ westwards to Repulse Havn in northern Nyeboe Land (Larsen \& Escher, 1985).

\section{Chester Bjerg Formation}

The formation was erected by Hurst \& Surlyk (1982). It corresponds to the uppermost of four informal sub-units briefly described by Dawes (1976, p. 279) and includes 'unit 1I' of Dawes \& Peel (1984).

The formation interfingers with and overlies the Nyeboe Land Formation and is the uppermost unit of the Peary Land Group exposed in western North Greenland (Hurst \& Surlyk, 1982; Larsen \& Escher, 1985).

The Chester Bjerg Formation can be no older than Ludlow at the base, and the top probably extends to the end of the Silurian (Hurst \& Surlyk, 1982; Dawes \& Peel, 1984; Larsen \& Escher, 1985). No unequivocal faunal evidence for the presence of Devonian strata within the formation has as yet been found.

The Chester Bjerg Formation has an extensive distribution in Hall Land, Nyeboe Land and on Hendrik $\varnothing$ (Larsen \& Escher, 1985). An isolated occurrence is found in Nares Land. 
Acknowledgements. We are thankful to A. K. Higgins, N. Henriksen and F. Surlyk for critically reviewing the manuscript. M. Bjerreskov is gratefully acknowledged for identification of the graptolite faunas. Finally, we thank B. Sikker Hansen, G. Hansen, B. Thomas, J. Lautrup and B. Larsen for technical assistance.

\section{References}

Berry, W. B. N., Boucot, A. J., Dawes, P. R. \& Peel, J. S. 1974: Late Silurian and early Devonian graptolites from North Greenland. Rapp. Grønlands geol. Unders. 65, 11-13.

Dawes, P. R. 1966: Lower Palaeozoic geology of the western part of the North Greenland fold belt. Rapp. Grønlands geol. Unders. 11, 11-15.

Dawes, P. R. 1976: Precambrian to Tertiary of northern Greenland. In Escher A. \& Watt, W. S. (edit.) Geology of Greenland, 248-303. Copenhagen: Geol. Surv. Greenland.

Dawes, P. R. \& Peel, J. S. 1984: Biostratigraphic reconnaissance in the Lower Palaeozoic of western North Greenland. Rapp. Grønlands geol. Unders. 121, 19-51.

Escher, J. C. \& Larsen, P.-H. 1987: The buried western extension of the Navarana Fjord escarpment in central and western North Greenland. Rapp. Grønlands geol. Unders. 133, 81-89.

Higgins, A. K. \& Soper, N. J. 1985: Cambrian-Lower Silurian slope and basin stratigraphy between northern Nyeboe Land and western Amundsen Land, North Greenland. Rapp. Grønlands geol. Unders. 126, 79-86.

Hurst, J. M. 1980: Silurian stratigraphy and facies distribution in Washington Land and western Hall Land, North Greenland. Bull. Grønlands geol. Unders. 138, 95 pp.

Hurst, J. M. \& Surlyk, F. 1982: Stratigraphy of the Silurian turbidite sequence of North Greenland. Bull. Grønlands geol. Unders. 145, 121 pp.

Larsen, P.-H. \& Escher, J. C. 1985: The Silurian turbidite sequence of the Peary Land Group between Newman Bugt and Victoria Fjord, western North Greenland. Rapp. Grønlands geol. Unders. 126, 47-67.

Larsen, P.-H., Edwards, D. \& Escher, J. C.: Late Silurian plant megafossils from the Peary Land Group, North Greenland. Rapp. Gronlands geol. Unders. 133, 107-112.

Surlyk, F. \& Hurst, J. M. 1984: The evolution of the early Paleozoic deep-water basin of North Greenland. Bull. geol. Soc. Am. 95, 131-154.

Surlyk, F. \& Ineson, J. R. 1987: The Navarana Fjord Member (new) - an Upper Llandovery platform derived carbonate conglomerate. Rapp. Grønlands geol. Unders. 133, 59-63. 